\title{
ERRATUM
}

\section{Erratum to: Synthesis of new Benzo[f]isoindole-4,9-diones as anticancer compounds}

\author{
Nipawan Pongprom - Hans Bachitsch - Arnulf Bauchinger - Hamid Ettefagh • \\ Tanja Haider • Manuela Hofer · Heike Knafl · Rita Slanz • Markus Waismayer • \\ Friedrich Wieser $\cdot$ Helmut Spreitzer
}

Published online: 11 March 2010

(C) Springer-Verlag 2010

Erratum to: Monatsh Chem (2010) 141:53-62

DOI 10.1007/s00706-009-0219-2

Unfortunately, the spelling of one author's name was incorrect.

The correct name should read Markus Waismayer.

The online version of the original article can be found under doi:10.1007/s00706-009-0219-2.

N. Pongprom $(\varangle) \cdot$ H. Bachitsch $\cdot$ A. Bauchinger .

H. Ettefagh · T. Haider - M. Hofer · H. Knafl - R. Slanz ·

M. Waismayer · F. Wieser · H. Spreitzer $(\bowtie)$

Department of Drug and Natural Product Synthesis,

University of Vienna, Althanstrasse 14, 1090 Vienna, Austria

e-mail: scnipapo@ubu.ac.th

H. Spreitzer

e-mail: helmut.spreitzer@univie.ac.at 